DOI No: http://dx.doi.org/10.29228/Joh.51463

Authenticity process is conducted by

Makale Türü: Araştırma makalesi

intihal.net

Geliş Tarihi: 21-05-2021

Kabul Tarihi: 25-10-2021

On-line Yayın: 31-10-2021

Article Type: Research article Submitted: 21-05-2021

Accepted: $25-10-2021$

Published Online: 31-10-2021

Atıf Bilgisi / Reference Information

Akcan Ekici, S. (2021). 1596 Yılı Ehl-i Hiref-i Hâssa Defteri Işı̆̆ında Sultan III. Mehmed Dönemi Sanat Ortam1. Journal of History School, 54, 3200-3224.

\title{
1596 YILI EHL-İ HİREF-İ HÂSSA DEFTERİ IŞIĞINDA SULTAN III. MEHMED DÖNEMI SANAT ORTAMI ${ }^{1}$
}

\section{Sakine AKCAN EKİC $\dot{I}^{2}$}

\section{$\ddot{\mathbf{O z}}$}

Adlî mahlası ile şiirler yazan Sultan III. Mehmed'in entelektüel bir kimliği olduğu, kendisine sunulan edebî eserleri ilgiyle karşıladığı bilinmektedir. Gerek babası Sultan III. Murad gerekse kendi dönemi çeşitli eserlerin yazılıp resmedildiği, sanat alanında üretkenliğin çok olduğu bir dönemdi. Her ne kadar Sultan III. Mehmed dönemi (15951603), özellikle siyasi ve ekonomik alanda kötü bir gidişat arz etse de kültürel ve sanatsal çalışmaların canlılığını korumaya devam ettiği bir zaman dilimi olmuştur. Özellikle sarayın bünyesinde varlığını devam ettiren Ehl-i Hiref-i Hâssa Teşkilatı aracılığıyla birçok farklı alanda, günümüze dahi gelebilen birbirinden ihtişamlı sanat eserleri ortaya konulmuştur. Devlet bünyesinde kurulup Osmanlı sanatına yön veren Ehl-i Hiref-i Hâssa Teşkilatı'nın ana kaynağı olan birçok maaş defteri bulunmaktadır. Çalışmada dönemin sanat dalları ve sanatkârlarının tespit edildiği bu defterlerden TSMA. D. 9613/2'de kayıtlı bulunan, 1596 yılı defteri 1şı̆̆ında Sultan III. Mehmed dönemi sanat ortamını oluşturan saray sanatkârları ele alınmıştır. Araştırmalar sonucunda Ehl-i Hiref-i Hâssa Teşkilatı'nın varlık gösterdiği süreç içerisinde sanatkâr sayısının en fazla olduğu dönemin Sultan III. Mehmed dönemi olduğu görülmüştür.

Anahtar Kelimeler: Sultan III. Mehmed, Ehl-i Hiref-i Hâssa, Osmanlı Sanatı, Osmanlı Sarayı.

\footnotetext{
${ }^{1}$ Bu makale "III. Mehmed Döneminde 1596-1601 tarihleri Arası Ehl-i Hıref Defterlerine Göre Sanatkârlar" adlı yüksek lisans tezinden üretilmiştir.

${ }^{2}$ Dr. Sakine Akcan Ekici, akcansakine@ hotmail.com. Orcid: 0000-0001-5594-180X
} 


\title{
The Artistic Environment of the Period of Sultan Mehmed III in the Light of the Ahl-i Hiraf-i Hâssa Registration Book Dated 1596 ${ }^{3}$
}

\begin{abstract}
Sultan Mehmed III, who wrote poems under the pseudonym Adlî, had an intellectual identity and is known for his interest in the literary works presented to him. The periods of both his father Sultan Murad III and himself were the periods in which various works were written and illustrated, and there was a huge productivity in the field of art. The period of Sultan Mehmed III (1595-1603) was a period in which cultural and artistic studies continued to maintain their vitality, even though it had a bad course, especially in the political and economic fields. Especially through the Ahl-i Hiraf-i Hâssa Organization, which continued to exist within the palace, magnificent art works had been produced in many different areas, which survive even today. There are many salary registration books, which are the main sources for the Ahl-i Hiraf-i Hâssa Organization established within the state and it directed Ottoman art. In the study, in the light of the registration book dated 1596 and under the TSMA. D. 9613/2, in which art branches and craftsmen of the period are identified, palace craftsmen of the period of Sultan Mehmed III who formed the art scene of the era are discussed. According to the results of the research, it was the period of Sultan Mehmed III when the Ahl-i Hiraf-i Hâssa Organization had the largest number of artists in its period of activity.
\end{abstract}

Keywords: Sultan Mehmed III, Ahl-i Hiraf-i Hâssa, Ottoman Art, Ottoman Palace.

\section{GİRIŞ}

Klasik dönem Osmanlı sanatı bir saray sanatı idi. Bu sanat saray ve çevresinin himayesindeki sanatkârların çalışmalarıyla şekil almıştır. Osmanlı sultanları gerek yapılan fetihlerle gerekse ülke içerisinde sanatta mahir olan birçok sanatçıyı etrafında toplayarak saraya bağlı bir teşkilat oluşturmuştur. Devletin bünyesinde oluşturulan bu teşkilata Ehl-i Hiref-i Hâssa denilmiştir. Saray'ın birçok ihtiyacını karşılayan sanatçı ve zanaatçılar ile cerrahlık, kehhâllik gibi, uzmanlık ve bilgi isteyen meslekleri içeren bu topluluk sarayın eğitimli üretim teşkilatı idi.

Hiref kelimesi hem sanat hem de zanaat sözcüklerini kapsayan ve nerdeyse el işçiliğine dayanan her tür üretimi içeren bir kavramdır (Sözen ve Tanyeli, 1986, s. 105). Osmanlı'da sanat ve zanaat için de hiref tabiri kullanılmaktayd1. Günümüzde zanaat maddi gereksinimleri karşılayan bir tabir iken, bu maddi

${ }^{3}$ This article has been produced from the master's thesis entitled "Craftsmen According to the Ahl-i Hiraf Registration Books Between 1596-1601 in the Period of Mehmed III. 
gereksinimlere yaratıcılık da eklendiğinde sanat tabiri ortaya çıkmaktadır. Ehl-i Hiref-i Hâssa üyeleri de saray için üretim yaptıklarından dolayı en kaliteli ham maddeleri kullanmış, ürettikleri eşyalara da yaratıcılıklarını katarak kıymetli ürünler ortaya koymuşlardır. Bundan dolayı Ehl-i Hiref-i Hâssa Teşkilatı bünyesinde olanların geneline sanatkâr demek yanlış olmasa gerektir (Akcan Ekici, 2018a, s. 17). Bununla birlikte Ehl-i Hiref-i Hâssa bünyesinde yer alan, sanatkâr ya da zanaatkâr tabiri için uygun olmayan cerrâhlar, müteferrika, bülbülcüler gibi sınıflar da vardır. Bu sınıflar az olmakla birlikte bunlar için hizmet sınıfı tabirini kullanmak daha doğrudur.

Nüvesinin Sultan II. Mehmed döneminde (1451-1481) oluştuğu, teşkilatlanmasının ise Sultan II. Bayezid döneminde (1481-1512) gerçekleştiği, rûznâmçe ve inâmât defterlerinde tespit edilmiş olan Ehl-i Hiref-i Hâssa'nın tam manasıyla müstakil bir yapıya kavuşması ise Sultan I. Süleyman (1520-1566) zamanında olmuştur. Dört asır kadar varlığını devam ettiren bu teşkilat bünyesinde kitap sanatlarından, kuyumculuğa, dokumadan maden sanatlarına kadar birçok sanat dalını barındırmaktadır. Bu sanat dallarının her biri cemâat olarak adlandırılmış olup cemâatlerin usta ve şakird adı verilen grupları bulunmaktadır. Şakirdler ustaların talebeleri konumundadır.

Ehl-i Hiref-i Hâssa Teşkilatı bünyesinde olan sanat dalları ve sanatkârlar günümüze kadar gelen çeşitli arşiv belgeleri ve özellikle teşkilatın maaş defterleri vasıtasıyla tespit edilebilmektedir. Teşkilatta yer alan tüm sanat dalları ve sanatkârlarının isimlerinin yanı sıra bazen detaylı bilgilerinin yer aldığı, ayrıca aldıkları ücretleri de gösteren defterlere Ehl-i Hiref-i Hâssa defterleri denilmektedir. Bu defterler Cumhurbaşkanlığı Devlet Arşivleri Başkanlığı Osmanlı Arşivi, Topkapı Sarayı Müzesi Arşivi ve Bulgaristan Devlet Arşivi olmak üzere üç arşivde yer almaktadır. Arşivlerde yer alan ve yapılan çalışmalar neticesinde şimdiye kadar tespit edilebilen 259 Ehl-i Hiref-i Hâssa defteri bulunmaktadır (Akcan Ekici, 2020, s. 2193). Tespit edilen defterler içerisinde en fazla sanatkârın yer aldığ 1 defter, çalışmada da ele alınan ve Sultan III. Mehmed dönemini içine alan 1596 tarihli defterdir. TSMA. D. 9613/2'de kayıtlı bulunan ve H. 1005/M. 1596 yılına tekabül eden bu defterde sarayın ihtiyaç duyduğu sanat ve zanaat ile hizmet grupları değerlendirilmiştir. Ayrıca farklı sanat dallarını ihtiva eden defter içerisinde yer alan sanatkâr sayıları da tespit edilmiştir. Aslında Sultan III. Mehmed dönemine ait dört tane Ehl-i Hiref-i Hâssa defteri bulunmaktadır. ${ }^{4}$ Fakat değerlendirmeye alınan defter teşkilatın varlık gösterdiği

${ }^{4} \mathrm{Bu}$ defterler, Devlet Arşivleri Başkanlığı Osmanlı Arşivi (BOA), Topkapı Sarayı Müzesi Arşivi Defterleri (TSMA.d), Defter No: 9613/1, Tarih: 1004 (1595); TSMA.d. Defter No: 1435, Tarih: 1005 (1596); TSMA.d, Defter No: 2924, Tarih: 1010 (1601)'de kayıtlıdır. 
süreç içerisinde sanatkâr sayısının en fazla olduğu defter olduğu için bilhassa ele alınmıştır.

Çalışmada ayrıca Sultan III. Mehmed hakkında kısa da olsa bilgi verilerek dönemin sanat ortamına, sarayın sanatkârları açısından bakılmıştır. Ehl-i Hiref-i Hâssa Teşkilatı hakkında çeşitli çalışmalar mevcut olduğundan burada tekrara gidilmemiştir. ${ }^{5}$

\section{Sultan III. Mehmed}

Manisa'nın Sart Ovası'nda dünyaya gelen Sultan III. Mehmed (26 Mayıs 1566), III. Murad ile Safiye Sultan'ın oğludur. Osmanlı Devleti'nin 13. hükümdarı olan III. Mehmed (1566-1603), şehzâdeliği döneminde ilk hocası İbrahim Cafer Efendi'den tahsil gördü. Onun vefatından sonra ise sırası ile Hüseyin Efendi, Pîr Mehmed Azmi Efendi ve daha sonra da Nevâlî Nasuh Efendi'den eğitim aldı. Sultan III. Mehmed'in saltanatı döneminde ise babası III. Murad'1n da hocası olan Sâdeddin Efendi bu görevi sürdürdü.

Sultan III. Mehmed sancakbeyliğinden gelerek padişah olan son şehzâdedir. Sancak Beyi iken kazandığı idarî tecrübeyi, padişahlığı döneminde pek kullanamamıştır. Bunun nedeni olarak da yumuşak tabiatlı olması, çabuk etkilenmeye müsait bir yapısının olduğu ve bundan dolayı da sarayda nüfuzu olan annesinin etkisinde kalması gibi nedenler gösterilmektedir (Emecen, 2003, s. 408; Gökbilgin, 1988, s. 547). Onun döneminde devlet adamları arasındaki mücadeleler ve içinde Valide Sultan'ın da yer aldığı gruplaşmalar dolayısıyla, birçok defa hükümet değişikliğine gidilmiştir.

Sultan III. Mehmed, babası Sultan III. Murad döneminde başlayan Osmanlı-Avusturya Savaşı devam ederken tahta geçmiştir. Tahta çıkar çıkmaz Avusturya ve Eflak sorunlarıyla ilgilenmiştir. Avusturya'da olduğu sırada Anadolu da ciddi tehlikelerle karşı karşıya kalmışıtır. Celali isyanları denilen Anadolu'daki ayaklanmalar ve İran'da başlayan ve savaşa dönüşen karışıklıklar Sultan III. Mehmed'in ve devletin gündemini uzun süre meşgul etmiştir.

Sultan III. Mehmed döneminin talihsiz olaylarından biri de Fatih Kanunnâmesi 'ndeki 'nizâm-1 âlem için kardeşlerinin katledilebilmesi' maddesi gereği olarak 19 şehzâdeyi boğdurtmasıdır. ${ }^{6} \mathrm{Bu}$ olaydan herkesin müteessir

${ }^{5}$ Detaylı bilgi için bkz. (Kırımtayıf, 1996; Akcan Ekici, 2018a; Yaman, 2008; Kazan, 2010; Bozcu, 2010)

${ }^{6} \mathrm{Bu}$ olayı birinci ağızdan öğreniyoruz: "Yevmü's-sebt fì Cumâdelûlâ, sene 1003. Bu gün yine seherden erkân-ı devlet ü saâdet ile vüzerâ-i izâm ve ulemâ-i kirâm ve meşâyih-i enâm dahi ma'ân Divân-ı mu'allâya hâzır olup, cümlesi mücevezzesiz libâs-ı mâtem-pûşîde, yerlü yerinde mukim ü 
olduğu gibi kendisinin de etkilenmemesi düşünülemez. Bu acı olay ile ve daha sonra taht kavgasını vereceğini düşündüğü oğlu Mahmud'u da aynı akıbete uğratması Sultan III. Mehmed'i çok sarsmış olmalıdır ki uzun ömürlü olamamıştır. Otuz sekiz gibi genç bir yaşta vefat etmiştir. Daha çok bu talihsiz olayla anılan III. Mehmed, aslında dönemindeki karmaşıklığa rağmen birçok yararlılıklar da göstermiştir. Babasının aksine halkı dinleyen, padişahlığı döneminde de cuma selamlıklarında ve gezilerde bu tavrını sürdüren Sultan III. Mehmed kendisinden önceki iki padişahın aksine, sefere çıkmış ve zaferler kazanmış bir padişahtır.

\section{Dönemin Sanat Ortamı}

Adlî mahlası ile şiirler yazan Sultan III. Mehmed'in entelektüel bir kimliği olup; kendisine sunulan edebî eserleri ilgiyle karşıladığı bilinmektedir. III. Mehmed döneminde, Gelibolulu Mustafa Âlî, Padişah hocası ve tarihçi Hoca Sadeddin Efendi, tarihçi Selânikî ve divan şiirinin önemli isimlerinden olan Nev’̂̂ ile Bâkî de onun saltanatı döneminin önde gelen simalarındandır.

Sultan III. Murad ve oğlu III. Mehmed dönemleri çeşitli eserlerin yazılıp resmedildiği, sanat alanında üretkenliğin çok olduğu bir dönemdi. Sultan III. Mehmed döneminde (1595-1603) bilhâssa tarihî konulu eserleri resimleyen ekip şehnâmeci Tâlikîzâde ve Nakkâş Hasan olmuştur. Bu ekip şehnâmeleri daha çok Türkçe olarak ele alıp şehnâmecilikte yeni bir dönem başlatmışlardı (Bağcı, Çağman, Renda \& Tanındı, 2006, s. 177).

Enderûn'da yetişen, minyatür ressamlığı ve tezhipçiliğiyle ünlü Nakkâş Hasan Paşa (öl. 1623) 1588-1601 yılları arasında yirmi kadar Türkçe olarak yazılmış tarihî ve edebî konulu eserin minyatürlerinin yapımında çalışmıştır. Bunların başında Şehnâmeci Tâlikîzâde Subhi Çelebi’nin, Sultan III. Mehmed'in Eğri seferini anlatan şehnâmesi olan Eğri Fetihnâmesi adlı eserin minyatürlerinin yapımı gelmektedir. Bu eserde Nakkâş Hasan, kendisine yakın gördüğü Gazanfer Ağa'yı Sultan III. Mehmed'in yanında resmetmiştir. Nakkâş Hasan, Tâlikîzâde'yi de eseri üzerinde çalışırken yalnız olarak bir portresini çizmiştir. Nakkâş Hasan, tezhip alanında da başarılı olup Sultan I. Ahmed'in tezhipli bir tuğrasını da yapmıştır (Tanındı, 2006, s. 330).

mütehayyır ve muntazır turup karâr eylediler ve mukaddemâ on dokuz nefer şehzâdeler içün serviden tabutlar ihzâr olunup ve cenazelerine lazım olan esbâb-ı mühimme hâzır u âmâde oldukta...” (İpşirli, 1999: s. 435-436; Ayrıca bkz. Peçevi İbrahim Efendi, t.y,: s. 164). 
Sultan III. Murad döneminde Şehnâmeci Seyyid Lokman ve Nakkâş Osman ekibinin, minyatürlü el yazmalarının hazırlanmasında önemli katkıları olmuştur. Sultan III. Mehmed, babası III. Murad döneminden kalan, Seyyid Lokman'ın hazırladığı Şehnâmelerin tamamlanmamış olmasına kızmış olmalı ki bu durum Seyyid Lokman'ın görevden alınmasına neden olmuştur (Çağman, 2004, s. 916). Böylece Sultan III. Mehmed Saray Şehnâmeciliğine Talikîzâde Mehmed b. Mehmed el- Fenari'yi (1596-97) getirtmiştir. III. Mehmed'in Eğri Seferi'ne katılan Talikîzâde ilk şehnâmesi olan “Eğri Fetihnâmesi”ni Nakkâş Hasan beraberliğinde bitirerek Sultan III. Mehmed'e sunmuştur. Eserin sonunda Nakkâş Hasan bir atölyede Tâlikîzâde'yi, eseri beyaza çeken hattatı ve kendisini çalışırken resmetmiştir (Çağman, 2004, s. 923). Yine Sultan III. Murad'ın isteği üzerine Erzurumlu Darîr'in yazdığı "Siyer-i Neb̂̀" adlı eserin minyatürlü bir nüshasının hazırlanması işi yarım kalmış, altı cilt olarak hazırlanan bu eser ancak III. Mehmed zamanında tamamlanmıştır (Kazan, 2007, s. 117).

Sultan III. Mehmed'in saltanatı süresince saray nakkâşları tarafından resimlendirilen eserlerin önemli bir kısmını Arapça ve Farsçadan çevrilen veya yeniden kaleme alınan edebi konulu kitaplar ve hikâyeler oluşturur (Çağman, 1995, s. 211). Örneğin 15. yüzyılda Abdurrahman b. Muhammed b. Alî b. Ahmed el-Bistâmi'nin yazdığ 1 cifr $^{7}$ ile ilgili eser, Sultan III. Mehmed'in isteği üzerine Şerif b. Seyyid Mehmed b. Şeyh Seyyid Burhan tarafından 1597-1598 yıllarında Arapçadan Türkçeye tercüme edilerek resimlenmiştir (Mahir, 2004, s. 65).

Yukarıda saydığımız bu eserler birçok sanatkârın ortak çalışmasıyla oluşmuştur. Yapılan bir eserde eseri istinsah eden kâtipler, kitabın her bir sayfasını süsleyen nakkâşlar, eser için çeşitli kaplar oluşturan mücellitler, kâğıtçılar, renkzenler, müzehhipler ve mürekkepçiler gibi ayrı gruplar halinde bir birliktelik oluşturularak birbirinden güzel eserler ortaya koymuşlardır.

$\mathrm{Bu}$ işleri yapan, farklı sanat dallarını bir araya getirerek bir sanat akademisi oluşturan Ehl-i Hiref-i Hâssa Teşkilatı idi. Birçok alanda saray yani devlet için üretim yapan bu teşkilatın başında ana görevleri saray kütüphanesi için hazırlanan el yazmalarının tezhip ve minyatürlerini yapmak olan nakkâşlar gelmektedir. Nakkâşların hazırladığı desenlerin, teşkilat bünyesindeki diğer birimlerin hazırladığı çiniden madene, kumaştan halıya kadar tüm eserlerde itina ile uygulanması sonucunda bir üslup ve desen birliği oluşmuştur.

Teşkilatın bünyesinde yer alan sanatkârların ortaya koyduğu kıymetli ürünlerin çoğunun hangi sanatçı tarafından hazırlandığı maalesef bilinmemektedir. Ancak, bazı yazma eserlerde ketebe sayfalarının olması

7 “Cifr" ya da "cefr" Gaipten haber verdiği söylenen ilim. 
1596 Y1lı Ehl-i Hiref-i Hâssa Defteri Işı̆̆ında Sultan III. Mehmed Dönemi Sanat Ortamı

hasebiyle sanatçının isminin yazılması ve yapılan bazı nesnelerde eseri yapan sanatkârın imzasının bulunması bunların Ehl-i Hiref-i Hâssa sanatçıları tarafindan üretildiğini göstermektedir(Çağman, 1984, s. 51-53).

Ehl-i hiref-i hâssa teşkilatı içerisinde kitap sanatları büyük önem arz etmekle birlikte kuyumculuk sanatı da Osmanlı padişahları tarafından sevilip desteklenmiş bir sanat dalıdır. Yavuz Sultan Selim ve Kanunî Sultan Süleyman şehzâdelikleri döneminde kumculuk sanatı ile iştigal ettikleri bilinmektedir (Kahraman \& Dağl1, 2003, s. 366).

Osmanlı saray kuyumculuğu Ehl-i Hiref-i Hâssa Teşkilatı içerisinde farklı sanat anlayışları ve gelenekleri olan ustaların işbirliği ile 16. yüzyılın ortalarına doğru kendine özgü bir şekil oluşturmuş olup 16. asrın sonunda ise en parlak dönemini yaşamıştır. Bu dönemde eserler üreten ve eserlerinde imzası bulunan Bosnalı Mehmed adlı sanatçı ön plandadır. Çağman'ın tespitine göre, Bosnalı Mehmed'in imzalı ve tarihli üç adet eseri saray hazinesinde yer almaktadır. Bunlardan birincisi Sultan III. Murad Divanı'nın kabıdır. Bu kap mücevher ve altındandır. Divan'ın kapağının dışında Bosnalı Mehmed'in imzası yer almaktadır. İkincisi Hırka-i Saadet sandığıdır. Bu sandık ahşap olup üzerine altın kaplama yapılmıştır. Sandığın içi altın levhalarla kaplı olup eserde Bosnalı Mehmed'in imzası ve H. 1001 (1592-1593) tarihi bulunmaktadır. Üçüncüsü de Kâbe için yaptırılan asma kilit ve anahtardır. Sultan III. Murad tarafindan yaptırılan asma kilit ve anahtar gümüş üzerinde altın yaldız olarak yapılmıştır. Bosnalı Mehmed'in imzalı eserlerinden 1588 yılında sarayın kuyumcubaşısı olduğu anlaşılmaktadır (Çağman, 1984, s. 51-53). Ayrıca saray hazinesinde yer alan değerli taşlarla süslü altın bir mataranın da Sultan III. Murad, III. Mehmed ve I. Ahmed dönemlerinde 1606 yılına kadar saray kuyumcubaşısı olan Bosnalı Mehmed'in imzalı eserlerine benzerliği dolayısıyla onun eseri olabileceği düşünülmektedir (Çağman, 1987, s. 87).

Bosnalı Mehmed, H. 1005/M. 1596 tarihli Ehl-i Hiref-i Hâssa defterinde serzergerân olarak kuyumcuların başında yer almıştır. En son 1014/1605 tarihli Ehl-i Hiref-i Hâssa defterinde serzergerân olarak görülen Bosnalı Mehmed, 1015/1606 tarihinde yerini Bosnalı Cafer'e bırakmıştır (Akcan Ekici, 2018a, s. $12)$.

\section{3. $1005 / 1596$ Tarihli Defterin Özellikleri ve Defterde Yer Alan Cemâatler}

Defter, Topkapı Sarayı Müzesi Arşivi'nde D. 9613/2 numarada yer almaktadır. Hicri aylardan muharrem, safer ve rebiülevvel aylarını 
kapsamaktadır. Defterin 15 varakla birlikte bir de "Defter-i mevâcib-i cemâ'at-i Ehl-i Hiref der vâcib-i masar sene hamse ve elf" yazısının bulunduğu giriş sayfası bulunmaktadır. Herhangi bir tahribatın bulunmadığı defter siyakat yazı türü ile yazılmıştır. Defterde çeşitli sanat dalları cemâat adı altında sıralanmıştır. Bu sanat dalları altında usta ve şakirdân -talebe diyebileceğimiz- isimleri her sıraya 5 kişi gelecek şekilde yazılmıştır. Defterde yer alan cemâat sayısı 44'tür. Bu bölümde söz konusu cemâatler yani sanat dalları tek tek ele alınarak onlar hakkında kısa da olsa bilgi verilecek ve defter içerisinde önemli kısımlara değinilecektir.

\subsection{Cemâat-i Kâtibân-ı Kütüb-i Hâssa}

Eser yazanların, kitap yazımı ile iştigal eden hattatların yer aldığı bu cemâat defterde ilk sırada yer almaktadır. Saray için kıymetli eserler, hat levhaları, berat ve fermanlar yazan kâtipler gerektiğinde bunların tamir işleri ile de uğraşmışlardır. Defterde kâtiplerin sadece usta sınıfı bulunmakta olup şakirdân yani talebeler bulunmamaktadır. Ustaların sayısı 61 olup birinin öldüğ̈̈ ve birinin de cemâtten ayrıldığı bilgisi ile beraber toplamda 59 kişi kalmışlardır. Kâtiplerden biri Bosnalı biri de Şirvanlı'dır. Cemâatte en yüksek ücret 35,5 akçe olup ücreti Ahmed Mehmed isimli kâtip almıştır.

\subsection{Cemâat-i Mücellidân-ı Hâssa}

Cild Arapça kökenli bir kelime olup deri anlamına gelmektedir. Ciltleme işinde en uygun malzeme olan derinin kullanılması dolayısıyla bu isimle anılmıştır. Ciltleme işini yapan, cilt sanatı ile uğraşanlara da mücellid denilmektedir (Arıtan, 1993, s. 551). Daha önce el yazmas1 eserlerin korunmas1 için yapılan ciltleme, Müslümanlığın yaygınlaşması ile birlikte dini eserlere verilen önem neticesinde İslam dünyasında bir sanat haline gelmiştir (Akcan Ekici, 2018b, s. 221). Saray için hazırlanan el yazması eserlerin ciltlerini yapan mücellitlerin ustalarından 2 sanatkârın vefat bilgisi bulunmakta olup 25 usta, 14 de şakirdân olmak üzere toplamda 39 mücellit defterde yer almaktadır. Ayrıca ustalar arasında kethüdâ unvanını sahip Rum asıllı olduğu anlaşılan Hürrem adlı bir mücellit de bulunmaktadır. Mücellitlerden Abdi Şa'ban, 24,5 akçe ile en yüksek ücreti alan sanatçıdır.

\subsection{Cemâat-i Külahdûzân-ı Hâssa}

"Külah", ucu sivri veya yüksek başlık demek olup diğer adı ise serpuştur. "dûz" ise Farsça bir kelime olup dikici, diken anlamındadır (Devellioğlu, 2006, s. 533, 192). Külah yapımı ile uğraşan bu cemâatin ustaları 31, şakirdânı ise 24 
kişi olup toplamda 55 üyesi bulunmaktadır. Ayrıca cemâatte serkülâhî, kethüdâ, sebölük ve seroda unvanları da bulunmaktadır. Külahçılar içerisinde Bosnalı olduğu anlaşılan ve bölükbaşı olan Bâlî Bosna 33,5 akçe ile en yüksek ücreti alan kişi olmuştur.

\subsection{Cemâat-i Zerdûzân-ı Hâssa}

İncelediğimiz lügatlerde zerduzân için sırma işleyenler, simkeşler denilmektedir (Pakalın, 1983, s. 654; Sâmi, 2006, s. 684; Devellioğlu, 2006, s.1180). Fakat defterde sîmkeşler ayrı bir cemâat olarak geçmektedir. Aralarındaki fark ise şu şekildedir: sîmkeşler, altın ve gümüşü dokumada veya işlemede kullanılacak şekilde hazırlarken, zerduzân ise sîmkeşlerin üretmiş olduğu bu malzemeyi kullanarak işlemelerini yapmışlardır (Yaman, 1996, s. 49). Şakirdân grubu olmayan zerdûzların 2 ustası bulunmakta olup en yüksek ücreti 17,5 akçe ile Mehmed İbrahim almıştır.

\subsection{Cemâat-i Nakkâşân-ı Hâssa}

Ehl-i Hiref-i Hâssa Teşkilatı'nın en önemli bölüklerinden olan bu cemâat, nakış sanatı ile ilgili her türlü işi yapmakla mükelleftiler. İçerisinde yer alan ressamlar, musavvirler, şebihnüvisler (portreciler), meclisnüvisler, siyahkalemler, müzehhibler, renkzenler, tarrâhlar (resim, daha çok bahçe resmi yapanlara denir), cetvelkeşler, duvar nakkâşları bunların hepsi nakkâş cemâati içerisinde yer alırdı (Meriç, 1956, s. VIII). İncelediğimiz defterde en çok sanatkârın bulunduğu cemâat nakkâşlar olmuştur. 66 ustası bulunan nakkâşların 64 de şakirdi ile birlikte toplamda 130 nakkâş vardır. Fakat defterde 4 nakkâşın vefat ettiği, bir kişinin de ayrılıp kapıcı olduğu, 4 şakirdin de usta sınıfına geçtiği -isimleri hem usta hem de şakirdler içinde bulunduğundan iki kez yazılmış oluyor- bilgisi yer almaktadır. Bu nedenle sarayın Ehl-i Hiref-i Hâssa Teşkilatı'nda mevcut olan toplamda 121 nakkâş vardı diyebiliriz. Ayrıca 4 nakkâşın da Kâbe-i Şerîf'e gittiği bilgisi bulunmakla birlikte gitmeleri görevlerinden ayrıldığı anlamına gelmediği için nakkâşların sayısına dâhil edilmişlerdir. Nakkâşlar içerisinde sernakkâş, kethüdâ, sebölük ve seroda-i evvel ve seroda-i sâni olmak üzere tüm unvanlar bulunmaktadır. Ayrıca bazı isimlerin nereli ve hangi milliyetten oldukları bilgisi de mevcuttur. İki Freng, birer Gürcü, Arnavut, Boşnak, Tiflisli ile Bursalı ve iki de Edirneli sanatkârların bulunduğu nakkâşların bazılarının hangi sanatı yaptıkları defterde yer almaktadır. Bunlar musavvir, rengzen, nakkâş, şehnâmeî adı ile bazı isimlerin altında yazılmıştır. Sernakkâşân olarak Lütfi Abdullah, 60 akçeyle bu cemâat içerisinde en yüksek ücreti alan kişi olmuştur. 


\subsection{Cemâat-i Gazzâzân-ı Hâssa}

Saray terzileri arasında ipek işleyenlerin, ipekçilerin bulunduğu cemâattir. Arapça "kazzaz" lafzından bozmadır (Sertoğlu, 1986, s.120; Pakalın, 1983, s. 655). İpek işleyen bu cemâatin 49 ustası 20 de şakirdi bulunmaktadır. Fakat 2 ustanın vefat bilgisi, bir ustanın da şakird sınıfına geçtiği, 2 gazzâzın da ayrılarak çavuş ve sipahi oldukları belirtilmiştir. Neticede toplamda sarayın 64 ipekçisi olduğunu söyleyebiliriz. Bunlardan iki kişi Kıbrıslı birer kişi de Bosnalı, Gürcü ve Akçahisarlı'dır. Defterde 34 akçe ile en yüksek ücreti sergazzâz olan Yusuf Abdullah isimli sanatkâr almıştır.

\subsection{Cemâat-i Zergerân-ı Hâssa}

Zerger'in çoğulu olan zergerân, kuyumculuk işi ile uğraşanların bulunduğu cemâattir. Çalışmalarında kıymetli taşlar kullanan zergerler fildişi, balık dişi, sedef gibi malzemeler de kullanarak takı dışında günlük kullanıma dair eşyalar da üretmişlerdir (İrepoğlu, 2012, s. 557). Zergerlerin 56 ustası 55 de şakirdânı bulunmaktadır. Defterde 3 zergerin öldüğ̈̈, bir şakirdin usta, birinin de müteferrika-i ehl-i hiref cemâatine gitmesi ile bir ustanın da sipahi olduğu bilgisi ışığında toplamda 105 zerger kalmıştır. Zergerlerde serzerger, kethüdâ ve seroda unvanları bulunmaktadır. İncelediğimiz defterde serzergerân olarak cemâatin başında bulunan Bosnalı Mehmed'in daha önce de ifade edildiği gibi imzalı ve tarihli üç tane eseri saray hazinesinde yer almaktadır. Zergerler içinde birer Boşnak, Gürcü, Freng, Arnavut, Çerkes, Macar ve 2 de Rum asıllı, bir de Trabzonlu bulunmaktadır. Bosnalı Mehmed en yüksek ücreti alan zerger olup ücreti 51 akçedir.

\subsection{Cemâat-i Hakkâkân-i Hâssa}

Hâk, Arapça'da oymak, kazımak anlamına gelir. Şemseddin Sâmi (2006, s. 554) Hakâk için maden veya herhangi bir şeyin üzerine çelik kalemle yazma sanatı diye bahseder. Hakkâk tabiri daha çok mühür kazıcılar için kullanılırdı (Sertoğlu, 1986, s. 131). Taş, tahta vs. üzerine oyma suretiyle yapılan süsleme ya da yazı yazma sanatını yapan bu cemâatin 28 usta 27 de şakirdi vardır. Bir şakirdin vefat bilgisi ile toplamda 54 hakkâk bulunmaktadır. Kethüdâ ve iki de serbölük unvanının yer aldığı cemâatte 2 Çerkes, birer Arnavud, Engürüs ve Eğribozlu vardır. Cemâatte 32 akçe ile en yüksek ücreti alan kişi de serbölük olan Çerkes Kasım adlı hakkâktır. 
1596 Yılı Ehl-i Hiref-i Hâssa Defteri Işı̆̆ında Sultan III. Mehmed Dönemi Sanat Ortamı

\subsection{Cemâat-i Sikkekenân-ı Hâssa}

"Sikkeken", darphanede para ve madalya kalıplarını yapmakla uğraşanlara verilen addır (Pakalın, 1983, s. 220). Bu tabir incelediğimiz defterlerde sikkegiyân ya da sikkekünân şeklinde yazılmıştır. Fakat sözlüklerde bu okunuşlara tesadüf edilmediğinden Uzunçarşıllı'nın da okuduğu gibi sikkekenân şeklinde yazıldı. On yedi ustanın, 4 de şakirdin yer aldığı cemâatte serbölük unvanı bulunmaktadır. En yüksek ücreti 29 akçe ile bölükbaşı olan Mehmed Tûrhân adlı sanatçı almıştır.

\subsection{Cemâat-i Zernişânyân-ı Hâssa}

"Zer" Farsça bir kelime olup, altın manasına gelir. "Nişân" ise, kılıç vs. üzerine yapılan süs, yazı anlamlarına gelmektedir (Sâmi, 2006, s. 674). Kakma altınla metal üzerine süsleme yapanların bulunduğu cemâatte 4 usta 6 da şakirdân vardır. Cemâatte Rum asıllı Hüsrev adlı sanatkâr serbölük olarak yer almış olup en yüksek ücreti de 25 akçe ile Ali Küçük isimli sanatkâr almıştır.

\subsection{Cemâat-i Kündekârân-ı Hâssa}

Kündekârî, geometrik şekillerde kesilmiş küçük ahşap parçaların çivi veya yapıştırıcı yardımı olmaksızın yalnızca birbirine geçirme suretiyle düz yüzeyler oluşturan bir tekniktir. $\mathrm{Bu}$ tarzda işler yapan marangozlara kündekârân denilmektedir (Uzunçarş̧11, 1988, s. 463). Kendekârân diye de okunabilen bu kelime bu sefer kalemkârlar manasına gelmektedir (Pakalın, 1983, s. 242). Bu cemâatin şakirdânı olmayıp ustalarından biri Çerkes biri de Boşnak olmak üzere toplam 15 kiși vardır. Cemâatte bölükbaşı unvanlı Ferûh ${ }^{8}$ Abdullah isimli sanatkâr 36,5 akçe ile en yüksek maaşı alan sanatkâr olmuştur.

\subsection{Cemâat-i Postîndûzân-ı Hâssa}

Postîndûz, sarayın terzileri arasındaki kürkçüler için kullanılan bir tabir olup kürk dikim işiyle uğraşanların oluşturduğu cemâattir (Pakalın, 1983, s. 780) Kırk usta 14 de şakird olmak üzere toplam 54 sanatkârı bulunan cemâatin serposztîndûzân, kethüdâ ve serbölük unvanları bulunmaktadır. Ayrıca şakirdler içinde Ahmed Mustafa kethüdâzâde kaydıyla yer alan ismin usta sınıfinda bulunan kethüdanın oğlu olduğu anlaşılmaktadır. 2 Boşnak ve Gürcü’nün, birer

\footnotetext{
${ }^{8}$ Ya da Fürûğ diye de okunabilir.
} 
de Rum, Macar ve Arnavud'un bulunduğu cemâatin bölükbaşısı olan Macarlı Cafer 27 akçe ile en yüksek ücreti alan kişi olmuştur.

\subsection{Cemâat-i Şemşîrgerân-ı Hâssa}

Şemşîr Farsça k1lıç anlamına gelmekte olup şemşirgerân ise kılıç yapan, işleyen sanatkâr demektir (Uzunçarş1l1, 1988, s. 464; Devellioğlu, 2006, s. 989). Saray için üretim yapıldığından sanat değeri yüksek olan kılıçları işleyen bu cemâatin 13 ustası ve 12 de şakirdi vardır. Bir ustanın vefat bilgisi ile birlikte toplamda cemâatin 24 sanatkârı vardır. Bunların arasında birer Macar, Arnavud ve Gürcü bulunmaktadır. Cemâattte serbölük unvanlı İbrahim 16 akçe ile en yüksek ücreti alan kişi olmuştur.

\subsection{Cemâati Kârdgerân-ı Hâssa}

Farça'da "kârd" bıçak manasına gelmektedir. Kârdgerân ise bıçakçılar, bıçak yapanlar demektir (Uzunçarşı1l, 1988, s. 463; Devellioğlu, 2006, s. 201). Saray bıçakçılarının yer aldığı cemâatte 21 usta ve 20 şakird bulunmakta olup bir usta ve bir şakirdin vefat ettiği cemâatin toplam sayısı 39 kişidir. Serbölük unvanı bulunan cemâatin içinde birer Arnavud, Macar ve 2 de Boşnak yer almaktadır. En yüksek ücreti alan kârdger cemâatte bölükbaşı olan ve 35 akçe alan Mehmed Abdullah olmuştur.

\subsection{Cemâat-i Bozdoğanîyân-ı Hâssa}

Bozdoğaniyân bir nevi savaş aleti olan topuzun yapımı ile iştigal edenlerin oluşturduğu cemaattir (Çağman, 1988, s. 76). Şakirdânı olmayan cemâatin 5 ustası vardır. 8,5 akçe ile Osman (?) adlı en yüksek ücreti alan kişi olmuştur.

\subsection{Cemâat-i Niyâmgerân-ı Hâssa}

Farsça bir isim olan "niyâm" kılıf, kın, kılıç kını anlamına gelir. Niyâmgerler kılıç, bıçak, hançer gibi şeylerin kabını yapan ustalardır (Devellioğlu, 2006, s. 842; Pakalın, 1983, s. 701). Şakirdlerle birlikte toplamda 12 sanatkârın bulunduğu cemâatte iki serbölük ve bir de kethüdâ unvanları bulunmaktadır. Kıncılardan en yüksek ücreti 16,5 akçe ile cemâatin bölükbaşısı olarak geçen Ali Mustafa adlı sanatçı almıştır. 
1596 Yılı Ehl-i Hiref-i Hâssa Defteri Işı̆̆ı̆nda Sultan III. Mehmed Dönemi Sanat Ortamı

\subsection{Cemâat-i Kemângerân-ı Hâssa}

"Kemânger" Farsça yay yapan sanatkârlara verilen isimdir (Devellioğlu, 2006, s. 506) Kemângerler için 1206/1792 yılı Ehl-i Hiref-i Hâssa defterinde yaycı açıklaması konulmuştur (BOA, TSMA.d, Defter No: 1406, Tarih: 1206 (1792), s. 4). Yay yapan sanatkârların 24'ü usta 21'i de şakird olmak üzere 2 ustanın vefat ettiği bilgisi de dikkate alınarak, toplam sayısı 43'tür. Cemâatte 2 serbölük bir de kethüdâ unvanı bulunmaktadır. Bölükbaşı olan Mihaliçli ${ }^{9}$ Şaban 47 akçe ile en yüksek ücreti alan kişi olmuştur.

\subsection{Cemâat-i Tîrgerân-ı Hâssa}

Farsça'da "tîr" ok demek olup tîrgerân ise ok yapan sanatkârlar manasındadır. Tîrgerler padişahların ve saray halkının kullanacağı okları imal ederlerdi. Ayrıca yabancı hükümdarlara hediye edilecek okları da yine bu cemâat imal ederdi (Pakalın, 1983, s. 508). Otuz iki ustası olan okçuların biri Bosnalı'dır. 7 de şakirdi bulunan cemâatin sertîreî, kethüdâ ve iki de sebölük unvanı bulunmaktadır. Serbölük unvanlı Mustafa Hüseyin 35 akçe ile en yüksek ücreti alan sanatkâr olmuştur.

\subsection{Cemâat-i Siperdûzân-ı Hâssa}

Bir savaş aleti olan kalkanları yapan siperdûzân için, genelde cemâat isimlerinin Türkçe yazıldığı bir Ehl-i Hiref-i Hâssa defterinde Cemâat-i kalkancılar ismi kullanılmıştır (BOA, TSMA.d, Defter No: 9612/1, Tarih: 965966 (1557-1558), s. 5). Şakirdânı olmayan cemâatin 4 ustası vardır. Bunlardan serbölük unvanlı ve Bosnalı olduğu anlaşılan Behrâm Bosna adlı sanatkâr en yüksek ücret olarak 31 akçe almıştır.

\subsection{Cemâat-i Kazgânyân-ı Hâssa}

Kazganyân, kazancıların, bakırcıların oluşturduğu bir cemaattir (Uzunçarş1l1, 1988, s. 463). Kazgânyân için 1206/1792 tarihli Ehl-i Hiref-i Hâssa defterinde kazancı yani bakırcl ifadeleri yer almaktadır (BOA, TSMA.d, Defter No: 1406, Tarih: 1206 (1792), s. 5). On sekiz ustanın, 31şakirdin olduğu cemâatte şakirdlerden birinin vefat ettiği hesaba katılarak toplamda 48 kazancı olduğu söylenebilir. Bunlardan biri Bosnalı biri de Rum asıllıdır. Cemâatte sadece 2 serbölük unvanı mevcut olup serbölüklerden biri olan Hamza Abdullah 35 akçe ile en yüksek ücreti alan kişi olmuştur.

${ }^{9}$ Mihaliç, Bursa'nın Karacabey ilçesinin eski adıdır. 


\section{Sakine AKCAN EKİİ}

\subsection{Cemâat-i Çilingîrân-ı Hâssa}

Adından da anlaşılacağı üzere çilingirlerin yer aldığı bir cemâattir. Çilingir, demir ve çelikten kilit, anahtar yapan sanatkâra denilir (Sâmi, 2006, s. 515). Yirmi bir ustadan 2 kişinin, 15 çıraktan da birinin vefat ettiği belirtilen cemâatte toplam 33 çilingir vardır. İki serbölük unvanı bulunan cemâatin içinde bir Rum asıllı olan Ahmed adlı sanatkâr en yüksek ücret olarak 18 akçe almıştır.

\subsection{Cemâat-i Dımışkîgerân-ı Hâssa}

Dımeşkîger genellikle Şam'da yapılan kılıç ve bıçak demiri için kullanılan bir tabirdir. Dımeşkîgerler çeşitli silah aletlerinin yapımında kullanılmak üzere hazırlanmış kaliteli demir ve çeliği hazırlayanların oluşturduğu cemâattir (Çağman, 2001, s. 52). Şakirdlerin olmadığı cemâatte 7 usta vardır. Ustalarından birinin kâtipler cemâatine gittiği görülmüştür. Serbölük unvanı olan Arnavudlu Hasan 16 akçe ile cemâatte en yüksek ücreti alan kişi olmuştur.

\subsection{Cemâat-i Saztıraşân-ı Hâssa}

Şemseddin Sâmî (2006, s. 698-699) "saz" için; sazdan yani kamıştan yapılan ney gibi çalgı aletlerine verilen isim diye bahseder. Saztıraşân çalg1 aletleri yapanların oluşturduğu cemaattir (Uzunçarşıl1, 1988, s. 464). Bu cemâatin şakirdleri yoktur. 20 sanatkârın olduğu cemâatte bir ustanın vefatı ile sayı 19 olmuştur. Sebölük unvanı olan cemâatte genelde nakkâşlar içinde yer alan bir de rengzen vardır. Yapılan aletlerin boyalarını bu sanatkârın yaptığı muhtemeldir. Cemâatte en yüksek ücret 10,5 akçe olup Abdi İsmail'e verilmiştir.

\subsection{Cemâat-i Neccârân-ı Hâssa}

Arapça bir kelime olan "neccâr" doğramac1, dülger, marangoz anlamlarına gelmektedir (Pakalın, 1983, s. 666). Marangozlar 34 kişi olup şakirdleri bulunmamaktadır. Serbölük ve kethüdâ unvanları mevcut olan marangozların içinde ikisi Rus birer Çerkes, Freng ve Rum yer almıştır. 26 akçe ile en yüksek ücreti cemâatin bölükbaşısı olan Mehmed Freng ${ }^{10}$ almıştır.

${ }^{10}$ Freng ya da Efrenç, Osmanlı Devleti'nin Avrupalılar, özellikle de Fransızlar için kullandıkları isimdir. (Pakalın, 1983: s. 635). 
1596 Yılı Ehl-i Hiref-i Hâssa Defteri Işı̆̆ında Sultan III. Mehmed Dönemi Sanat Ortamı

\subsection{Cemâat-i Camgerân-ı Hâssa}

Camciların, cam yapan ya da camdan eşyalar üretenlerin oluşturduğu bu cemâattin şakirdân grubu bulunmamaktadır. Camcıların mevcudu 11 kişi olup içlerinde bir Macar bir de Varnalı sanatkâr vardır. Cemâatte en yüksek ücreti de 18 akçe ile cemâatin bölükbaşısı da olan Keyvân Abdullah almıştır.

\subsection{Cemâat-i Harrâtîn-i Hâssa}

Harrâtlar cemâati için çıkrıkçı, doğramacı ifadeleri kullanılmıştır (Uzunçarşı1lı, 1988, s. 464). Kâmûs-1 Türkî' de çıkrıkçı için de ağaçtan çeşitli eşyalar yapan doğramacı diye bahsedilir (Sâmi, 2006, s. 529) Evliya Çelebi de harratîn için çıkrıkçılar esnafı ifadesini kullanmıştır (Kahraman, Dağlı, 2003, s. 622). Şakirdi olmayan cemâatin biri Bosnalı olmak üzere 13 üyesi vardır. Serbölük unvanı olan Bayram Abdullah isimli sanatkâr 20,5 akçe ile en yüksek ücreti alan kişi olmuştur.

\subsection{Cemâat-i Mûzedûzân-ı Hâssa}

"Mûze" Farsça'da çizme anlamına gelmekte olup "dûz" ise yine Farsça olup dikici, diken manalarına gelmektedir (Sâmi, 2006, s. 625). Çizme dikenlerin, imal edenlerin oluşturduğu cemâatte sanatkâr sayısı oldukça fazladır. Elli iki ustası ve 41 şakirdi ile toplamda 93 kişi olan çizmecilerin içinde 5 Boşnak, 4 Gürcü ve birer Çerkes, Bulgar, Rum, Macar ve Rus bulunmaktadır. Serbölük ve kethüdâ unvanları olan çizmecilerin içinden Cafer Abdullah isimli sanatkâr en yüksek ücret olan 20,5 akçe almıştır.

\subsection{Cemâat-i Debbâğîn-i Hâssa}

Arapça bir kelime olan "debbâğ" hayvan derilerini sepileyerek (tabaklayarak) meşin, kösele vs. yapanlara denir (Sâmi, 2006, s. 602). Debbâğcıların yer aldığı bu cemâatin 12 üyesi olup şakirdi yoktur. Cemâatte alınan ücretlerin genelinin düşük, en yüksek ücretin de 3 akçe olduğu ve ücretin Ridvan Hasan adlı debbağa verildiği görülmüsstür.

\subsection{Cemâat-i Kemhâbâfân-ı Hâssa}

"Kemhâ" bir çeşit ipekli kumaşa, havsız (tüysüz) kadifeye verilen addır. "Bafân" ise Farsça'da dokumak manasındadır (Sâmi, 2006, s. 1182; Pakalın, 1983, s. 506). Genelde kaftan yapımında kullanılan bu kumaş türünü dokuyanlara kemhâbâfân denilmektedir. Kemhâ dokuyucuların oluşturduğu bu cemâatin 
ikisinin vefat ettiği 41 ustası 16 da şakirdi ile birlikte toplamda mevcut olan 55 üyesi vardır. Serbölük ve kethüdâ unvanları da olan kemhâcılar arasında 3 Arnavud, 3 Boşnak, 2 Çerkes, birer de Freng, Macar ve Rus yer almaktadır. Cemâatten Ahmed Kasım Çavuş 26 akçe ile en yüksek ücreti alan sanatkâr olmuştur.

\subsection{Cemâat-i Kadifebâfân-ı Hâssa}

Bir kumaş türü olan "kadife"; ipek, pamuk ve yünden yapılan havlı, ince kumaş manasındadır (Sâmi, 2006, s. 1076). Kadife dokuyanların oluşturduğu bu cemâatte 11 üyenin olduğu bunlardan birinin vefat ettiği yazılmıştır. Kalan 10 sanatkârın içinde 3 Çerkes, bir Arnavud ve Macar bulunmaktadır. Cemâat içerisinde en yüksek ücret 25 akçe olup Arnavudlu olduğu anlaşılan Keyvân Arnavud isimli sanatkâra verilmiştir.

\subsection{Cemâat-i Nakşbendân-ı Hâssa}

Arapça bir isim olan "nakş" kelimesi bildiğimiz üzere resim, süsleme sanatı anlamına gelmektedir. "Bend" ise Farsça bir kelime olup bağlama, bağlamak anlamına gelmektedir. Birleşik isim oluşturan "nakşbend" ise "kumaşların nakışlarını bağlayıp, ipek tellerle tezgâha hazırlayan kimse, süslemeli dokuma sanatkârı manasına gelmektedir (Devellioğlu, 2006, s. 803). Şakirdi olmayan naşbendlerin sayısı ise birinin vefatıyla 8 kişi kalmıştır. Bunlardan biri Rum'dur. Cemâatte en yüksek ücret 35,5 akçe olup ücreti alan kişi Behrâm isimli sanatkârdır.

\subsection{Cemâat-i Sîmkeşân-ı Hâssa}

Farsça'da "sîm" gümüş manasına gelmekte olup sîmkeşân, ise haddeden" gümüş tel çeken sanatkârlar anlamına gelmektedir (Sâmi, 2006, s. 759). Sırmakeşler diye de tabir olunan bu cemâat için 1206/1792 yılı Ehl-i Hiref-i Hâssa defterinde sirmakeş açıklaması konulmuştur (BOA, TSMA.d, Defter No: 1406, Tarih: 1206 (1792), s. 6). Şîmkeşler 21 usta ve 14 şakirdden mürekkep olup bir ustanın vefatı, 2 şakirdin de sipahi olup ayrılması neticesinde toplamda 32 kişi kalmışlardır. Bunlardan biri Rum asıllıdır. Sîmkeşlerde 2 serbölük olmak üzere kethüdâ ve seroda unvanları bulunmaktadır. Cemâat içerisinden Ali Abdullah en yüksek ücreti alan kişi olup 30 akçe almıştır.

${ }^{11}$ Hadde: "Erimiş mâdenden tel yapmak için kullanılan delikli mâden levha", (Devellioğlu, 2006: s. 308). 
1596 Yılı Ehl-i Hiref-i Hâssa Defteri Işı̆̆ında Sultan III. Mehmed Dönemi Sanat Ortamı

\subsection{Cemâat-i Zerkûbân-ı Hâssa}

Zerkûb, Farsça bir kelime olup altın döven, altın tozu yapan sanatkârlara denilirdi (Pakalın, 1983, s. 655). Saray için hazırlanan eserlerde kullanılmak üzere altın varak malzemeyi üretmekle görevli olan bu cemâatin sanatkâr sayısı 10 kişidir. Ahmed zerkûb adlı sanatkâr 12 akçe ile cemâat içerisinde en yüksek ücreti alan kişi olmuştur.

\subsection{Cemâat-i Abâbâfân-ı Hâssa}

" $A b \hat{a}$ " yünden yapılan kalın kumaşlara ve bu kumaştan yapılan hırka gibi üstlüklere denilir (Sâmi, 2006, s. 925). Abâ dokuyucuların oluşturduğu bu cemâatin şakirdleri bulunmayıp biri Macar olmak üzere toplamda 25 üyesi vardır. Cemâatte 25 akçe en yüksek ücret olup ücreti Osman Ferhad adlı sanatkâr almıştır.

\subsection{Cemâat-i Kaliçebâfân ve Sorguçiyân-ı Hâssa}

"Kaliçebâfân", küçük halı ve seccade dokuyan sanatkârlara denilir (Pakalın, 1983, s. 151). "Sorguç" ise esas manada bazı kuşların tepesinde bulunan uzun tüylere verilen addır. Fakat zamanla erkek ve kadın başlıklarının (serpuş, kavuk, fes hotoz vs.) üzerine takılan süs için de bu tabir kullanılmıştır (Tarım Ertuğ, 2009, s. 378-379). Başka defterlerde ayrı gruplar halinde bulunan bu iki cemâat, incelediğimiz defterde aynı grup altında verilmiştir. İki sanat dalının bir arada bulunduğu cemâatin şakirdân grubu yoktur. Cemâatte çalışan sanatkârların 13 olan sayıs1, birinin vefatı ile toplam 12 olmuştur. Bir Macar bir de Gürcü'nün yer aldığı cemâatte en yüksek ücreti Haydar Abdullah isimli sanatkâr almıştır. Haydar Abdullah'ın aldığı ücret 35 akçedir.

\subsection{Cemâat-i Câmeşûyân-ı Hâssa}

"Câme" Farsça' da elbise anlamında olup "şûy" ise temizlemek, y1kamak manasına gelen "şüş̧ten" masdarından gelir (Sâmi, 2006, s. 466). Çamaşır yıkayıcıları olarak bilinen bu cemâatin sadece sarayın çamaşırlarını yıkamadığı, iç çamaşırı için keten kumaş dokuyup; çeşitli giysiler diktikleri de tahmin edilmektedir (Bozcu, 2010, s. 50). Yirmi iki ustanın ve 18 şakirdin yer aldığ 1 cemâatin toplam 40 üyesi vardır. Serbölük ve kethüdâ unvanları bulunan çamaşırcıların içerisinde 4 Avlonyalı, birer de Eğriboz ve Karahisarlı bulunmaktadır. Defterde çamaşırcıların usta sınıfında yer alan sanatkârların genelde yüksek ücret almaları dikkat çekici olmakla birlikte en yüksek ücret 26 akçedir. Ücreti cemâatte bölükbaşı olan Ali almıştır. 


\subsection{Cemâat-i Kâşîgerân-ı Hâssa}

Kaşîgerân çini yapan sanatkârlara verilen addır (Devellioğlu, 2006, s. 494). Esasında "Kâş̧ı"', İran'ın Kâşân kentinde imal edilen sırlı ve renkli çini manasına gelmektedir (Sâmi, 2006, s. 1138). Buna binaen bu işi yapan sanatkârlara kâşı̂̀gerân ismi verilmiş olabilir. Çiniciler bulunduğu bu cemâatin şakirdi olmayıp toplam 5 üyesi vardır. En yüksek ücret 7 akçe olup Osman adlı sanatkâr ücreti alan kişi olmuştur.

\subsection{Cemâat-i Buhûrciyân-ı Hâssa}

Farsça bir isim olan "buhûr" tütsü, (Sâmi, 2006, s. 282) yani güzel koku elde etmek için, yakılan kokulu ağaç ve maddeler anlamına gelmektedir. Bu işi yapan sanatkârlara da buhûrciyân denilir. Şakirdi olmayan cemâatin 6 ustası olup bir buhûrcunun, tîrgerân yani okçuların bulunduğu cemâate geçtiği bilgisi ile sayıları 5 kişi kalmıştır. Bu cemâatte en yüksek ücreti alan kişi Nasûh Mehmed adlı sanatkâr olup 17 akçe almıştır.

\subsection{Cemâat-i Cerrâhîn-i Hâssa}

"Cerrâhîn" Arapça cerrâh kelimesinin çoğulu olup hekimler, doktorlar manasına gelmektedir. Cerrâhların içerisinde göz hekimleri manasına gelen kehhâller de bulunmaktadır. Başka defterlerde farklı cemâatler halinde verilmişken ele alınan defterde kehhâller de cerrâhlar içerisinde verilmiştir. 78 usta cerrâhın içinde 12 kehhâl bulunmaktadır. 33 şakird içinde de 5 kehhâl mevcuttur. Ustalardan 5 kişinin vefat ettiği dikkate alınarak cemâatte toplamda 106 kişi vardır. Bunlar içerisinde iki Çerkes ve birer Freng, Macar, Gürcü, Boşnak ve Sigetvar ile Kıbrıslı bulunmaktadır. Cemâatin genelinde çalışanların aldıkları ücret yüksektir. Şakirdlerin ücretleri de diğer cemâatlerdeki şakirdlere kıyasla daha fazla olduğu söylenebilir. Cerrâhların şakirdlerinin aldığı en az ücret 3 akçedir. Oysa diğer cemâatlerde en az ücret 1 akçeye kadar düşebilmektedir. İncelenen defterde söz konusu cemâatte yer alan Ramazan adlı cerrâh, enyüksek ücreti alan kişidir. Ramazan'a 40,5 akçe tahsis edilmiştir.

\subsection{Cemâat-i Çırakcıyân-ı Hâssa}

Çırakcılar saray için kandil, mum gibi aydınlatmayı sağlayan araçları imal edenlerin bulunduğu cemâattir (Sâmi, 2006, s. 507). Şakirdi olmayan çırakcıların mevcudu 7 kişidir. Cemâatte alınan en yüksek ücret 17 akçe olup Malkoç Abdullah ücreti alan sanatkâr olmuştur. 
1596 Y1lı Ehl-i Hiref-i Hâssa Defteri Işı̆̆ında Sultan III. Mehmed Dönemi Sanat Ortamı

\subsection{Cemâat-i Bûriyâbâfân-ı Hâssa}

Farsça bir isim olan "bûriyâ", hasır manasına gelmektedir. Bûriyâbâfân ise hasır dokuyanlar, hasırcilar anlamında kullanılır (Devellioğlu, 2006, s. 114). Hasırcıların yer aldığı bu cemâatte serbölük unvanı da bulunmaktadır. Şakirdi olmayan cemâatin 5 ustası olup bunlardan 27 akçe en yüksek ücreti alan kişi, serbölük unvanlı olan Abdurrahman Abdullah isimli sanatkârdır.

\subsection{Cemâat-i Küştigîrân-ı Hâssa}

"Küştigerân" diye de okunabilen bu cemâat, Uzunçarşılı ve Pakalın tarafindan marangozlar diye tarif edilmiştir (Uzunçarşıl1, 1988, s. 464; Pakalın, 1983, 345). Fakat sarayda Neccârân yani marangozlar cemâati mevcuttur. Farsça gemi anlamına gelen "keştî̀" ve gemi yapan anlamına gelen "keştîger" tabiriden dolayı bu grup için saray kayıklarıyla iştigal eden cemâat de denilmiștir (Yaman, 1996, s. 122). Fakat küsstigîrân diye de okunabilen bu kelime bu kez güreşçiler manasına gelmektedir. Bu cemâatin güreş̧̧ilerden mürekkep olduğunu söylemek de mümkündür. Yirmi yedi üyesi bulunan cemâatin şakirdleri yoktur. Cemâatte en yüksek ücreti İdris Abdullah 8 akçe olarak almıștır.

\subsection{Cemâat-i Müteferrika-i Ehl-i Hiref}

Arapça bir isim olan "müteferrika" hükümdar ve devlet adamlarının çeşitli hizmetlerinde bulunan kişiler için kullanılan bir tabirdir (Pakalın, 1983, s. 637; Sertoğlu, 1986, s. 234). Müteferrikalık sistemi 16. yüzyılın sonlarında değişime uğramıştır. Önceleri itina ile seçilen kadrolara, daha sonra kâtip, çavuş gibi devlet görevlileri de dâhil olmuştur. Yani dergâh-1 âlî müteferrikalarının yanı sıra müteferrika tabiri, vezir ve diğer çeşitli vazife sahiplerinin maiyetinde bulunan hizmet erbabı için de kullanılmıştır. Örneğin hasahır müteferrikaları, yeniçeriler arasındaki șikâr ve solak müteferrikaları, șahinci ve çakırcı müteferrikaları gibi (Afyoncu, 2006, s.183, 185) Görüldügüü üzere müteferrika bir hizmet bölügünü oluşturmaktadır. Ehl-i Hiref-i Hâssa Teşkilatı içerisinde de yer alan müteferrika sınıfının da bu kategoriye girdiğini söylemek mümkündür. Yani söz konusu müteferrika cemâati, Ehl-i Hiref-i Hâssa Teşkilatı üyelerine hizmet eden, onların işlerini kolaylaştıran bir sınıf olduğunu düşünmek makuldür (Akcan Ekici, 2018a, s. 141-142). Cemâatin 45 ustası ve 42 şakirdi vardır. Şakirdlerden üçü usta sınıfina geçmiştir. Böylece toplamda cemâatin 84 üyesi bulunmaktadır. Bunlar içerisinde 2 sarraç, bir kehhâl ve bir de muvakkit var. Ayrıca cemâatin içerisinde 2 Macar ve Freng ile birer Arnavud, Çerkes, Gürcü ve Bulgar da bulunmaktadır. 
Muvakkit ${ }^{12}$ olduğu belirtilen Halil muvakkit, 22 akçe ile cemâatte en yüksek ücreti alan kişi olmuştur.

\subsection{Cemâat-i Müteferrik}

Arapça bir sıfat olan "müteferrik" ayrı ayrı, dağınık manasına gelmektedir (Devellioğlu, 2006, s. 765). Müteferrik, müteferrika cemâatinden ayrı olarak maharetlerini ispat edenlerin zaman içerisinde diğer cemâatlere transferlerinin yapıldığı ve defterlerde görülebileceği üzere farklı sanat dallarından olanların bir arada bulunduğu bir cemâattir. Örneğin müteferrik cemâatinde yer alan ve kehhâl oldukları belirtilen üç kişi cerrâhlar, iki kişi gazzâzân, birer kişi de mûzedûzân ve zergerân cemâatine geçmiştir. Bir kişinin de cemâatten ayrılarak sipahi olduğu bilgisi bulunmaktadır. Defterde 29 ismin yer aldığı müteferrik cemâatinde söz konusu bilgiler dikkate alınarak cemâatin toplamda 21 üyesi olduğu söylenebilir. Ücretlerin çok düşük olduğu bu cemâatte en yüksek 10 akçe olmuştur. Ücreti cemâatten Ferhat Abdullah almıştır.

\section{SONUÇ}

Sultan III. Mehmed döneminde (1595-1603) özellikle Avusturya ve İran'la yapılan savaşların getirdiği yük Osmanlı Devleti'nin ekonomisini büyük ölçüde sikıntıya sokmuş olmasına rağmen kültür ve sanat ortamı canlılığını devam ettirmiştir. $\mathrm{Bu}$ canlılığı sağlayan ve Osmanlı sanatını şekillendiren kuşkusuz Ehl-i Hiref-i Hâssa Teşkilatı olmuştur. Bu dönemde hattatlar tarafindan yazılan ve itina ile tezhiplenen Mushaf'ların dışında özel olarak oluşturulan birçok eser hazırlanmıştır. Tezhipli, minyatürlü kıymetli cildler içindeki kitaplar, desen ve dokumaları ayrı ayrı kıymetli olan kumaşlar, halılar, çiniler, değerli taşlarla süslenen eşyaların desen ve tasarımları Ehli Hiref-i Hâssa Teşkilatı üyeleri tarafından meydana getirilmişti.

Fatih Sultan Mehmed döneminde (1444-1481) şekillenen Ehl-i Hiref-i Hâssa Teşkilatı akabinde ve Sultan III. Mehmed döneminde devletin önemli kurumlarından birisiydi. Bu dönemi içine alan 1005/1596 tarihli Ehl-i Hiref-i Hâssa defteri içindeki sanat ve zanaat dalları ile sanatkâr sayıları yapının önem ve büyüklüğünü göstermektedir.

Topkap1 Sarayı Müzesi Arşivi D. 9613/2 numarada yer alan defterde toplam 44 cemâat ismi bulunmaktadır. Kitap sanatları, maden, silah yapımı, dokuma ve ahşap sanatları gibi alanlarda çalışan sanatkârların toplam sayısı ise

12 Zamanı özellikle de namaz vakitlerini tayin eden kişiye Muvakkit denilir.

[3219] 
1596 Y1lı Ehl-i Hiref-i Hâssa Defteri Işı̆̆ında Sultan III. Mehmed Dönemi Sanat Ortamı

1544'tür. Fakat defterin genelinde bazı sanatkârın öldüğü, bazılarının kapıcı, çavuş, sipahi olmak üzere teşkilattan ayrıldığı, bazılarının da cemâatler arasında yer değiştirmesi sonucunda isimlerinin iki kez yazılması göz önünde bulundurularak yapılan toplam reel sayının 1487 olduğu ortaya çıkarılmıştır. Defter içinde 121 üyesi ile ilk sırada nakkâşların yer aldığı, ikinci sırada ise 106 kişiyle cerrâhlar, üçüncü sırada ise 105 sanatkâr ile zergerlerin yer aldığı görülmüştür. En az kişinin bulunduğu cemâat ise 2 üyesi ile zerdûzân ve 4 üyesi ile de kalkan yapan siperdûzan bulunmaktadır.

Defterde ayrica toplam 116 sanatkârın memleket veya milliyetleri belirtilmiştir. Teşkilat içinde 22 kişi ile en fazla Boşnak'ların bulunmaktadır. 17 Arnavud, 14 Çerkes, 14 Gürcü, 13 Macar, 11 Rum, 8 Freng, 4 Rus ve 3 de Bulgar'ın bulunduğu defterde, 3 Kıbrısl1, 2 Bursa, 2 Eğriboz, 1 Karahisar, 1 Şirvan, 1 de Trabzonlu ismi geçmektedir. Cemâatler içerisinde memleket ve milliyetleri belirtilenler 14 kişi ile en fazla mûzedûzlerdir. Sonrasında sırasıyla 11 kemhâbâfân, 9 zergerân, 7 nakkâş ve 7 postindûz gelmektedir.

Ehl-i Hiref-i Hâssa hakkında yapılan çalışmalar ve arşiv araştırmaları neticesinde 1005/1596 tarihli Ehl-i Hiref-i Hâssa defteri, teşkilatın varlık gösterdiği süreç boyunca sanatkâr sayısının en fazla olduğu defter olmuştur. Sultan III. Mehmed dönemini kapsayan defterde gerek cemâat sayıları gerekse de çalışan sanatkârların çokluğu bakımından bu dönem için sanat ve kültürel alanında verimliliğin de çok olduğu bir dönem olduğu söylenebilir.

\section{KAYNAKÇA / REFERENCES}

\section{Arşiv Kaynakları}

T. C. Devlet Arşivleri Başkanlığı Osmanlı Arşivi (BOA)

Topkapı Sarayı Müzesi Arşivi Defterleri (TSMA.d), Defter No: 9613/2, Tarih: 1005 (1596); TSMA.d, Defter No: 1406, Tarih: 1206 (1792); TSMA.d. Defter No: 9612/1, Tarih: 965-966 (1557-1558).

\section{Kitap ve Makaleler}

Afyoncu, E. (2006). Müteferrika, Türkiye Diyanet Vakfi İslâm Ansiklopedisi içinde (Cilt. 32, s.183-185). TDV yayınları.

Akcan Ekici, S. (2018a). 17. Yüzyılda Osmanlı Devleti'nde Ehl-i Hiref-i Hâssa Teşkilatı Birimleri ve Yapısal Özellikleri. Yayınlanmamış doktora tezi, İstanbul Üniversitesi Sosyal Bilimler Enstitüsü. 
Akcan Ekici, S. (2018b). 17. yüzy1l saray mücellitleri. Akademik Sosyal Araştırmalar Dergisi, 86, 219-238.

Akcan Ekici, S. (2020). 1801 tarihli ehl-i hiref-i hâssa defterinde osmanlı devletinin sanatkârları. Journal of History School, 47, 2187-2221. http://dx.doi.org/10.29228/joh.45244

Arıtan, A. S. (1993). Ciltçilik, Türkiye Diyanet Vakfi İslâm Ansiklopedisi içinde (Cilt. 7, s. 551-557). TDV yayınları.

Bağcı, S., Çağman, F., Renda, G., \& Tanındı, Z. (2006). Osmanlı Resim Sanatı. Kültür ve Turizm Bakanlığı.

Bozcu, P. (2010). Osmanlı Sarayında Sanatçı ve Zanaatçı Teşkilatı Ehl-i Hiref. Yayınlanmamış uzmanlık tezi, Kültür ve Turizm Bakanlığı Kültür Varlıkları ve Müzeler Genel Müdürlügüu.

Çağman, F. (1984). Serzergerân mehmed usta ve eserleri. Kollektif (Ed.), Kemal Çı̆̆'a Armă̆an içinde (s. 51-87). Topkapı Sarayı Müzesi Müdürlüğü yayınları.

Çağman, F. (1987). Altın hazine matarası. Topkapı Sarayı Müzesi Yıllık 2 içinde (s. 85-122). İstanbul matbaası yayınları.

Çağman, F. (1988). Mimar sinan döneminde sarayın ehl-i hiref teşkilâtı. Z. Sönmez. (Haz.), Mimar Sinan Dönemi Türk Mimarlığı ve Sanatı içinde (s. 73-77). Türkiye İş Bankası yayınları.

Çağman, F. (1995). Tarihi gelişimi içinde osmanlı sarayı minyatürleri. M. Özel. (Haz.), Geleneksel Sanatlar Türk Sanatları içinde (s.187-227). Kültür Bakanlığı yayınları.

Çağman, F. (2000). Behind the ottoman canon the works of the imperial palace. Palace of Gold And Light Treasures From The Topkapı içinde (s.46-56). Palace Arts Foundation.

Çağman, F. (2004). Minyatür. Osmanlı Uygarlı̆̆ C. II, H. İnalcık, G. Renda. (Haz.). Kültür ve Turizm Bakanlığı yayınları.

Devellioğlu, F. (2006). Osmanlıca-Türkçe Ansiklopedik Lûgat. Aydın kitabevi yayınları.

Emecen, F. (2003). III. Mehmed, Türkiye Diyanet Vakfi İslâm Ansiklopedisi içinde (Cilt 28, s.407-413). TDV yayınları.

Gökbilgin, M. T. (1993). Mehmed III, İslam Ansiklopedisi içinde (C. 7, s. 535547) Milli Eğitim Bakanlığı yayınları. 
1596 Y1lı Ehl-i Hiref-i Hâssa Defteri Işı̆̆ında Sultan III. Mehmed Dönemi Sanat Ortamı

İpşirli, M. (1999). Tarih-i Selânikî I-II. Türk Tarih Kurumu.

İrepoğlu, G. (2012). Osmanlı Saray Mücevheri. Bilkent kültür girişimi.

Kahraman, S. A., Dağl1, Y. (2003). Evliya Çelebi Seyahatnâmesi: İstanbul I. Yap1 Kredi.

Kazan, H. (2007). XV. ve XVI. Asırlarda Osmanlı Sarayının Sanatı Himayesi. Yayınlanmış doktora tezi, Marmara Üniversitesi Sosyal Bilimler Enstitüsü.

Kırımtayıf, S. (1996). XV. Ve XIX. Yüzyıllar Arasında Osmanlı Saray Sanatı Teşkilatı. Yayımlanmamış doktora tezi, İstanbul Teknik Üniversitesi Sosyal Bilimler Enstitüsü.

Mahir, B. (2004). Osmanlı Minyatür Sanatı. Kabalc1.

Meriç, R. M. (1953). Türk Nakış San’atı Tarihi Araştırmaları I Vesikalar. Türk ve İslâm San'atları Tarihi Enstitüsü.

Pakalın, M. Z. (1983). Osmanlı Tarih Deyimleri ve Terimleri Sözlüğ̈̈̈ I-III. Milli Eğitim Bakanlığı yayınları.

Peçevi İbrahim Efendi (t.y.). Tarih-i Peçevî C. I-II. Matbaa-y1 Âmire.

Sâmî, Ş. (2006). Kâmûs-ı Türkî. Çă̆rı yayınları.

Sertoğlu, M. (1986). Osmanlı Tarih Lûgatı. Enderun kitapevi.

Tanındı, Z. (2006). Nakkâş hasan paşa, Türkiye Diyanet Vakfi İslâm Ansiklopedisi içinde (Cilt. 32, s. 329-330). TDV yayınları.

Tarım Ertuğ, Z. (2009). Sorguç, Türkiye Diyanet Vakfi İslâm Ansiklopedisi içinde (Cilt. 37, s. 378-380). TDV yayınlar1.

Uzunçarşı1ı, İ. H. (1986). Osmanlı sarayında ehl-i hiref sanatkârlar defterleri. Belgeler Türk Tarih Belgeleri Dergisi. 11,15, 23-76.

Uzunçarşı11, İ. H. (1988). Osmanlı Devleti'nin Saray Teşkilâtı. Türk Tarih Kurumu.

Yaman, B. (1996). 18. yüzyılın II. yarısında osmanlı saray ehli hiref teşkilatı. Süleyman Demirel Üniversitesi İlâhiyat Fakültesi Dergisi, 3, 85-107. 


\section{EXTENDED ABSTRACT}

The reign of Mehmed III (1595-1603) was a period while witnessing negative trends in political and economical areas, cultural and artistic studies flourished and maintained their vitality. In this period various works of arts written and depicted and performance increased in arts and it was Ehl-i Hiref-i Hâssa Organization that performed arts and crafts. Thanks to this organization, which was established within the state and manufactured for the Palace, magnificent works of art were created in many different fields from book arts andjewelery toweaving, wood engraving and metal arts.

Ehl-i Hiref-i Hâssa Organization created an art academy by bringing together different branches of art and the most prominent among them were the miniature artists whose main task was to make the illumination and miniatures of the manuscripts prepared for the palace library. The artworks had been formed by the joint work of many artists. For example, in an artwork, many separate groups came together to form a union and produce a masterpiece: The transcriptionist copied the work, the miniature artists decorated each page of the book, the bookbinders created various bindings, and other artists like papermakers, colorists, illuminators, and ink writers.

The art branches and the craftsmen that took part within Ehl-i Hiref-i Hâssa Organization can be identified through various archive documents and especially by the salary registration books of the organization. These books are called Ehl-i Hiref-i Hâssa books and they sometimes contain detailed information and also show the fees of the members, in addition to the names of all the art branches and craftsmen in the organization. These books are located in three archives: Turkish Republic Ottoman Archive of the Presidency State Archives, Museum Archive of Topkapı Palace and Bulgaria State Archive. There are 259 Ehl-i Hiref-i Hâssa registration books in the archives that have been identified so far as a result of the researches. Among the identified books, the 1596 dated book is examined in this paper which covers the reign of Sultan Mehmed III and has the most names of the artists. In this book which is registered as TSMA. D. 9613/2 and corresponds to Hijri 1005/C.E. 1596, the arts and crafts and services needed by the Palace is assessed. Also, the number of craftsmen is identified that is aforesaid in the book that involves different art branches. Actually, there four more Ehl-i Hiref-i Hâssa books belonging to the reign of Sultan Mehmed III. However, since this registration book which is under consideration involves the greatest number of artists for the guild's period of existence, it has been specifically addressed. Also, this paper gives a viewpoint towards the artists of the Palace by giving information about Sultan Mehmed III and the period's art environment. Since 
there are various studies about Ehl-i Hiref-i Hâssa Organization, these are not repeated here.

According to the Ehl-i Hiref-i Hâssa registration book of the year 1596, in which art branches and craftsmen of the period were identified in this study, there are 44 community that constituted the art environment of the period of Sultan Mehmed III.

The total number of artists performing in areas such as book arts, mining, weapon making, weaving and wooden arts is 1487. In total, for 116 artists the hometowns or nationalities information are also stated in this book. As a result of the studies and archive researches about Ehl-i Hiref-i Hâssa, it has been identified that the Ehl-i Hiref-i Hâssa book, dated 1005/1596, has the greatest numbers of crafsmen for the period of existence of the guild. By considering the registration book covering the period of Sultan Mehmed III, it is possible to say that this period was highly efficient in terms of arts and culture both in numbers of communities and arts and craftsmen. 